\title{
Changes in The Nature of social and cultural values; (District Sultanpur,U.P.) INDIA.
}

\author{
1. Dr. Indu Shekhar Upadhyay \\ Asso.Prof.Geography. \\ S.T.D.P.G.Collage Kadipur.India \\ 2. Dr. Veena Upadhyay \\ Assistt.Prof.Economics \\ Karamat Husain.Girls P.G.Collage.Lucknow.India
}

\begin{abstract}
Caste system is most important for Indian society. The castes found in Sultanpur district are determined on the basis of lineage and karma. The caste system is an important institution of Indian society. It is found not only in Hindu society, but also in Muslim and Christian societies. Intercaste marriage is also slowly becoming prevalent in the society. The caste system provides the basis for various work in the village or local village groups, which is necessary for social life.
\end{abstract}

Research methods: Rapid social change and the resulting diversification of life worlds are increasingly confronting social researchers with new social contexts and perspectives ... traditional deductive methodologies ... are failing ... thus research is increasingly forced to make use of inductive strategies instead of starting from theories and testing them ... knowledge and practice are studied as local knowledge and practice.

KEYWORDS: Social organization, beliefs and values, philosophy of life.

\section{Introduction}

There is a rapid change in the form. At present, the excess of single family and lack of joint family is reflected, which is the highest change in the composition of the lower and backward castes, while the lowest among the upper castes. In fact, the prevalence of single family among lower and backward castes is increasing. On the one hand, in the purdah system, there is deprivation, education of women, in upper and backward caste families, on the other hand, illiterate women do not like multiracial families in lower caste family and preach their husbands to settle down after getting married. It seems. Despite this, the attention of dignity and dignity is still present in the upper caste families. It is being disregarded by other castes, which is the main catalytic element of the solitary family.

Conclusions: Under the traditional social system, ethnic panchayats are formed for mutual organization in villages, which are made up of some villages of special caste people, which try to solve the problems of that particular caste. Many changes have also taken place in the rural organization after attaining independence. The trend of change in the traditional social system of Sultanpur district has started to be seen in the changing form of inter-village organization too. It is noteworthy that the importance of caste panchayats has now remained only among the lower and backward castes and it is also getting relaxed. While the upper castes disregard their decisions. As a result, the tendency to take cases of caste panchayats and intergovernmental organizations to government courts is increasing. In this way, many social, cultural, religious and moral and historical changes have taken place in Sultanpur district.

The social, cultural and economic life of the district Sultanpur depended mainly on rural values, practices and traditions. Despite various modern changes, the continuity of traditional systems and values still maintain their full complexity. Man keeps adapting or exploiting or refining various elements of the environment to fulfill his specific technological achievements, social organization, beliefs and values, philosophy of life, and needs, which makes man's particular way of life prevalent. In this way, the overall way of living of a particular region is given the noun of culture. Developed by practice in terms of language, personal conduct and ideal way of living, technology etc. Equality and government policies bind people in a cultural thread.

Individuals are the basic unit of society. He performs a variety of personal tasks, which are restricted in the social 
context, while many of his works are inconsistent in the immediate social environment and reflect long-term social changes. In this way personal work and social environment are embedded in interaction. This interaction between social environment and personal work is called social system. Under the social system, society's institutions, traditions, customs, communal and cultural values, streams of thought, attitudes, political and educational institutions, family, law and personal ethics are included. Thus "any social system or social environment in which an internal permanent or relatively permanent structure exists is called a social structure."

Caste System : The caste system is an important institution of Indian society. It is found not only in Hindu society, but also in Muslim and Christian societies. Inter-caste marriage is also slowly becoming prevalent in the society. The caste system provides the basis for various work in the village or local village groups, which is necessary for social life.

Regional model of castes: Caste system is most important for Indian society. The castes found in Sultanpur district are determined on the basis of lineage and karma. The main castes found in the district are Brahmin, Chamar, Ahir, Pasi, Kurm, Ambassador, Lodh, Koiri, Sheikh, Murav, Kahar, Gaderia, Kayastha, Mallah, Muslim etc. The regional distribution of castes in the study area particularly affects the social, economic and political condition. Although the area (political, economic and social) of social activities of different castes is changing due to the development and modernization of society, it is not going extinct. For the detailed study of the regional distribution pattern and social structure of castes in Sultanpur district, a personal ethnic survey of the villages Koiripur, Laxmanpur, Pagupur, Bhuvanshahpur and Alinagar was carried out and it was found that the Chamar caste resides in almost all the surveyed villages. The survey shows that the surveyed villages of Sultanpur district Koiripur (13.18 percent), Laxmanpur (13.15 percent), Pagupur (16.15 percent), Bhuvanshahpur (18.35 percent), Alinagar (8.35 percent) have the highest number of Chamars and the lowest Kayastha caste. In Koiripur (0.85 percent), Laxmanpur (0.95 percent), Pagupur ( 0.35 percent), Bhuvan Shahpur ( 0.85 percent), Alinagar $(0.35$ percent) are found.

Regional Functional Form - Generally, people of different castes have been traditionally doing different industries in the villages of Sultanpur district. Such as - washerman, barber, carpenter, blacksmith, potter, teli, wari, kahar, chamar, brahmin etc. This economic aspect of the caste system in the village is expressed in the Yajmani system. Under this custom, some castes expect people of other castes to do their services. For example, the carpenter, the blacksmith, makes the tools of the farmer, the hairdresser cuts the hair, the washerman

\section{Caste structure in Sultanpur district in percentage (2019)}

\begin{tabular}{|c|c|c|c|c|c|c|}
\hline S.N. & Caste & Koiripur & Laxmanpur & Paigupur & Bhuvan Shahpur & Alinagar \\
\hline 1. & Brahmin & 14.64 & 14.53 & 10.53 & 7.45 & 3.25 \\
\hline 2. & Chamars & 13.81 & 13.15 & 16.15 & 18.35 & 8.35 \\
\hline 3. & Ahir & 11.84 & 11.65 & 14.25 & 6.05 & 5.45 \\
\hline 4. & Pasi & 5.56 & 5.35 & 2.40 & 10.15 & 12.18 \\
\hline 5. & Kurmi & 2.60 & 2.75 & 0.95 & 2.15 & 7.28 \\
\hline 6. & Kshatriya & 7.00 & 6.85 & 8.65 & 8.10 & 8.15 \\
\hline 7. & Lodh & 3.84 & 3.80 & 3.15 & 3.15 & 2.18 \\
\hline 8. & coir & 3.47 & 3.78 & 5.65 & 3.25 & 3.27 \\
\hline 9. & Sheikh & 0.95 & 1.22 & 1.30 & 3.86 & 8.65 \\
\hline 10 & Moura & 1.38 & 0.48 & 2.00 & 2.15 & 4.35 \\
\hline 11 & kahar & 1.92 & 1.98 & 2.85 & 1.65 & 2.10 \\
\hline 12 & shepherd & 2.28 & 2.65 & 4.65 & 3.15 & 1.85 \\
\hline 13 & Kayasthas & 0.85 & 0.95 & 0.35 & 0.85 & 0.35 \\
\hline 14 & sailors & 1.60 & 2.15 & 5.15 & 3.25 & 3.45 \\
\hline 15. & Muslims & 4.03 & 3.45 & 1.15 & 4.15 & 14.26 \\
\hline 16. & other & 24.29 & 25.26 & 20.85 & 22.29 & 24.88 \\
\hline
\end{tabular}

Source: Personal Survey 2019. 
washes the cloth, the Brahmin performs the rituals, marriages and death ceremonies in almost all castes. The poor person of low caste lives as a plowman (who does agricultural work) in the dominated peasant caste. Kahar fills water. Adi is reflected in the expression system of caste economic aspect.

Occupational structure of castes - The survey shows that the occupation of different castes in Sultanpur district is not completely caste based. The economic business of the villagers is mainly dependent on agricultural work and commercial specialization and self reliance. For example, agricultural work is mainly done by Brahmin Kshatriyas, Ahirs, Kurmis etc. Other castes sustain themselves in agriculture and wage profession. Trade and business mainly do Teli, Kalwar, Baniya etc. Brahmins, Kshatriyas and Kayasthas were mainly involved in the job profession, but now people of other castes are also doing this work. The work of labor is done by the Chamar, Khatik, Dharkar etc. castes.

In the Sultanpur district, even today caste, traditional business or work continues. For example, Brahmins do worship and worship, along with doing religious work, cultivate their private land and also engage in jobs. Potter, barber, dhobi, teli, carpenter, blacksmith, chamar etc. castes are also associated with their traditional occupation as well as sowing and harvesting the crops in the village farmers and barns. At present, there is a shortage of agricultural labor in the villages due to the transfer of rural population towards the cities in the desire for higher living standards, due to which people are getting attention towards third occupation.

Teli, whose traditional business was to crush oil in the Sultanpur district, now, due to the facility of oil extraction by machines, other castes got into this business and the Teli caste has left this business. The change in occupation of Dhobi, Potters, Barber and Blacksmith castes is relatively less. The reason for this is that business people easily get their means of livelihood by working in both the village and the city. Similarly, the traditional occupation of carpenter and tailor castes has reduced. The main reason for this is that their business has increased relatively in furniture making, cloth sewing etc. People from other castes are also engaged in this business. Their business has increased due to increasing fashion and modern customs.

Basic Changes in Social Structure- After Independence, the promotion of civilization (westernization), urbanization and industrialization, modern education, other modern means of communication, especially in films, the increasing wave of freedom and equality in women, the process of culturalization and different types of values, from conflicts to social structures. There is a rapid change in the form. At present, the excess of single family and lack of joint family is reflected, which is the highest change in the composition of the lower and backward castes, while the lowest among the upper castes. In fact, the prevalence of single family among lower and backward castes is increasing. On the one hand, in the purdah system, there is deprivation, education of women, in upper and backward caste families, on the other hand, illiterate women do not like multiracial families in lower caste family and preach their husbands to settle down after getting married. It seems. Despite this, the attention of dignity and dignity is still present in the upper caste families. It is being disregarded by other castes, which is the main catalytic element of the solitary family.

Form of traditional social and cultural change- Through the conclusions obtained from the above studies, the process and factors of interpersonal, social, cultural change have been analyzed which are as follows -

Atrocities of castes: Today the highest castes and lower castes are almost certainly fixed, but there are fluctuations, laxities and changes between the two points. These changes have come in decades and are still active today. Some of these important changes are as follows -

The feeling of caste is strong - caste refers to sagotri, homogenous and relatives living in some nearby villages. Like before, castes are still bound in internal marriages and patterns. Caste is a part of and followed by traditional religion. In the society, a person gets certain benefits from joint family and caste, which is not available to anyone in the industrialized western countries. The feeling of casteism has become very strong due to caste reservation in education, jobs and socio-economic sectors. Caste reservation like reservation of caste and tribe and backward classes and casteism entering the political arena and at the same time the speeches made by political leaders in the context of caste-specific demands are increasing inter-caste discourse. Thus, where there is talk of ending casteism, in the practical world the strong feeling of casteism is increasing.

Relaxation in observance of caste rules: Although caste sentiment has prevailed, the rigor of observance of caste rules has continued to relax. This has become particularly visible in the study of relaxing villages, mainly in the rules related to food and behavior, thought and behavior. All castes in rural areas, whether high or low, violate food-related taboos when they move to the city. Another important change has also been seen in the behavior of people. They did not sit on a pedestal with a person belonging to a lower caste, and a higher caste person would leave the posture, but today it is relaxing. Actions like deteriorating economic condition, urbanization, progress in education etc. have affected the social prestige of upper castes more. As a result Whereas, at hotels and chat shops, they do not follow this rule and do it in villages. In the present time, strict restrictions have been relaxed, especially in relation to untouchability. As a result, the feeling of caste untouchability and impurity is coming down. This feeling is the result of culturalization.

Occupational dynamism in castes: As a result of the change in the social structure of the district, various castes are abandoning their traditional profession and are attracted 
towards new economic activities. It is clear from the study of the Kshatriya and Brahmin castes of the district that as a result of the Zamindari system in the British period, these castes did not themselves do agricultural work. But family growth and the abolition of zamindari attracted towards agriculture and for a few decades 100 percent of the families of these castes have been doing agricultural work. A few decades ago, hundred percent of Brahmin families used to do their traditional business (priest and priest), where today only a few families do this business. At present, these castes are becoming more oriented towards agriculture and jobs and trade. It is worth mentioning that due to being landless, the lower castes had to forcibly do service work at the homes of the rich people at negligible or nominal wages. Also his business did not receive any social respect. They had to do hard work or existence at home of their priests or in the fields under the Yajmani system. But in the last three decades, there has been a lot of change in their social life, the trend of wage business is getting relatively low, mainly due to land acquisition, job opportunities in outlying cities, loan facility on simple installments, tea-shop Opening, work available under NREGA scheme etc. are the responsible factors.

Organizational nature of villages: In Sultanpur district, under the traditional social system, ethnic panchayats are formed for mutual organization in villages, which are made up of some villages of special caste people, which try to solve the problems of that particular caste. Many changes have also taken place in the rural organization after attaining independence. The trend of change in the traditional social system of Sultanpur district has started to be seen in the changing form of inter-village organization too. It is noteworthy that the importance of caste panchayats has now remained only among the lower and backward castes and it is also getting relaxed. While the upper castes disregard their decisions. As a result, the tendency to take cases of caste panchayats and intergovernmental organizations to government courts is increasing. In this way, many social, cultural, religious and moral and historical changes have taken place in Sultanpur district. Changes in social system and cultural values have been continuous in cultural change, ethics, behavior, food, living and living. Under the social system, the institutions of the society, traditions, customs, social and cultural values, ideas, the nature of political and educational institutions, family and personal ethics are included. Dimensions of change are connected in the socio-economic structure of Sultanpur district. Even today, there is continuity in the main occupations of people related to traditional family business. However, due to the impact of mechanization, development in education, opportunities for outside jobs, inaccessible income for sustenance from population growth, these factors have started to sag. Due to the effect of the above reasons on family integrity and empowerment, their structure has also changed a lot. In the villages of the district also, due to increase in irrigation facilities and communication facilities due to electrification, the standard of living of the people has improved. Yet the pace of change in the socio-economic and social structure of the villages affected by illiteracy, poverty, conservative views is very slow. Therefore, there is a great need for rapid process of adequate improvement and development.

general well-being (dimensions of quality of work life) are found important and significant predictors of self-rated employees' performance but for manager-rated employees' performance only stress at work was found significant predictor. Since employees are working in the private sector organization, therefore, they experience more stress. Nature of organization is an important factor which play important role in experiencing the stress. Stress is inevitable part in employees' life. Therefore, organizations should work and develop stress management techniques for minimize the stress at workplace. Employees having high general well-being at workplace are more productive and their performance is also high. In this study PsyCap partially mediated the relationship between quality of work life and self-rated performance.

\section{REFERENCES}

1. Journal of Statistics: Sultanpur District (20017-18).

2. Singh, Santosh Kumar: Geological organization of rural elements and rural development: A study of Allahabad district.

3. Bechan and Singh, Mangla: Integrated Rural Development, Jeevandhara Publications, Varanasi.

Citation: Dr. Indu Shekhar Upadhyay and Dr. Veena Upadhyay, "Changes in The Nature of social and cultural values;(District Sultanpur,U.P.) INDIA.". American Research Journal of Humanities and Social Sciences, vol 7, no. 1, 2021, pp. 1-4.

Copyright (c) 2021 Dr. Indu Shekhar Upadhyay and Dr. Veena Upadhyay. This is an open access article distributed under the Creative Commons Attribution License, which permits unrestricted use, distribution, and reproduction in any medium, provided the original work is properly cited. 